\title{
The mineral resource assessment project, South-East Greenland: year one
}

\author{
Bo Møller Stensgaard, Jochen Kolb, Troels F.D. Nielsen, Símun D. Olsen, Llewellyn Pilbeam, \\ Diana Lieber and Anette Clausen
}

South-East Greenland between $62^{\circ} \mathrm{N}$ and $67^{\circ} \mathrm{N}$ is one of the lesser known regions in Greenland, having seen only limited geological investigations and only few detailed ones, with the Skjoldungen alkaline igneous province as a notable exception (Nielsen \& Rosing 1990). Systematically collected geoscientific data are scarce; however, such data are essential as a basis for geological models and for evaluation of the mineral potential. In order to open up the region for exploration, the Greenland Bureau of Minerals and Petroleum financed a two-year, mainly geochemical programme for 2009 and 2010 , which is an initial part of a five to six year project that involves subsequent geophysical surveys, a geological programme and a full-scale resource assessment of the region. The primary objective of the initial geochemical programme is to collect sediment samples for analysis of chemistry and indicator minerals. Supplementary to this, surface water for chemistry is collected and radiometric spectra of representative lithologies are measured. Geological reconnaissance field work focussing on selected key areas is also carried out.

During the past 10-15 years, the Geological Survey of Denmark and Greenland (GEUS) has carried out resource assessments of the Palaeoproterozoic orogens and mobile belts in South and central West Greenland, and most recently, assessments of the North Atlantic craton in West and southern West Greenland were conducted. The current assessment of South-East Greenland will provide the last major contribution needed for a detailed understanding of the Palaeoproterozoic and Archaean geological evolution of the entire southern Greenland, enabling us to develop new geological models for the region. The 2009 field work focused on the area between Timmiarmiit Kangertivat and Bernstorff Isfjord (Fig. 1).

\section{Regional geology}

The Archaean North Atlantic craton in South-East Greenland is bounded to the south and north, respectively, by the Palaeoproterozoic Ketilidian and Nagssugtoqidian mobile belts. The eastern part of the latter was formerly denoted the Ammassalik mobile belt (Andrews et al. 1973; Escher $\&$ Nielsen 1983). An overview of the region was provided by Chadwick et al. (1989).



Fig. 1. Geological map of part of South-East Greenland showing the distribution of sediment samples, surface-water samples, indicator mineral samples and radionetric measurements (black dots). The map is based on Escher (1990). NZ: northern zone. NS: Nordre Skjoldungesund. SAP: Skjoldungen alkaline province. TK: Timmiarmiit Kangertivat. 
Table 1. Differences between three main zones of the Archaean craton in South-East Greenland and encountered mineralisation

\begin{tabular}{|c|c|c|c|}
\hline $\begin{array}{l}\text { Subdivision of } \\
\text { the craton }\end{array}$ & Main lithologies & $\begin{array}{l}\text { Regional } \\
\text { structural grain }\end{array}$ & $\begin{array}{l}\text { Encountered mineralisations and } \\
\text { preliminary mineral potential }\end{array}$ \\
\hline $\begin{array}{l}\text { Northern zone } \\
\text { (NZ) }\end{array}$ & $\begin{array}{l}\text { Numerous layers of supracrustal rocks } \\
\text { dominated by mafic granulites. Grey } \\
\text { tonalitic to granodioritic gneiss }\end{array}$ & $\begin{array}{l}\mathrm{N}-\mathrm{S} \text { - to } \mathrm{E}-\mathrm{W} \text {-trending foliation } \\
\text { and folds with } \mathrm{W} \text {-plunging } \\
\text { fold axes }\end{array}$ & $\begin{array}{l}\text { Orthomagmatic } \mathrm{Ni}, \mathrm{Cu}, \mathrm{PGE} \text { and } \mathrm{Au} \\
\text { Hydrothermal alteration zones with } \\
\mathrm{Au}\end{array}$ \\
\hline $\begin{array}{l}\text { Skjoldungen } \\
\text { alkaline province } \\
\text { (SAP) }\end{array}$ & $\begin{array}{l}\text { Tonalitic to granodioritic gneiss, locally } \\
\text { agmatitic, supracrustal sequences, alkaline } \\
\text { intrusive rocks (granitic to syenitic- } \\
\text { monzonitic gabbro, carbonatite- } \\
\text { nephelinite rocks) }\end{array}$ & $\begin{array}{l}\text { Strong NW-SE-trending } \\
\text { foliation } \\
\text { Late conjugate sets of } \\
\text { NW-SE- and SW-NE- } \\
\text { trending foliation }\end{array}$ & $\begin{array}{l}\text { Alkaline and carbonatite intrusion- } \\
\text { related } \mathrm{Nb}, \mathrm{REE}, \mathrm{U} \text { and Th. } \\
\text { Hydrothermal alteration zone with } \\
\text { sulphides and quartz veins. } \\
\text { Porphyry } \mathrm{Cu} \text {, Sn and Mo deposits } \\
\text { Iron-oxide copper-gold deposits }\end{array}$ \\
\hline $\begin{array}{l}\text { Southern zone } \\
\text { (SZ) }\end{array}$ & $\begin{array}{l}\text { Agmatitic, tonalitic to granodioritic gneiss } \\
\text { Few restricted supracrustal sequences }\end{array}$ & $\begin{array}{l}\mathrm{N}-\mathrm{S} \text { - to NE-SW-trending } \\
\text { foliation and folds with } \\
\text { SE-plunging fold axes }\end{array}$ & $\begin{array}{l}\text { Hydrothermal alteration zone with } \\
\text { sulphides and quartz veins. } \\
\text { Alkaline intrusion-related } \mathrm{Nb}, \mathrm{REE} \\
\mathrm{U}, \mathrm{Th}\end{array}$ \\
\hline
\end{tabular}

The craton is dominated by orthogneisses with subordinate belts and slivers of supracrustal rocks (up to $1 \mathrm{~km}$ in width and several tens of kilometres along strike), and with late- to post-tectonic alkaline intrusions in the Skjoldungen area. The peak metamorphic facies is granulite grade. Retrogression from granulite facies to amphibolite facies assemblages is common. Based on lithological variation and regional structural grain the craton is subdivided into a northern zone (NZ), a Skjoldungen alkaline province (SAP) and a southern zone (SZ; Table 1; Fig. 1).

The orthogneiss is dominated by an early tonalitic generation intruded by syn- to late-tectonic tonalite and granodiorite, which have subsequently been intruded by post-tectonic granitic to granodioritic sheets (Andrews et al. 1973; Escher $\&$ Nielsen 1983). The early tonalitic gneiss is characterised by an agmatitic fabric with centimetre to metre scale, rounded to angular fragments of amphibolite, meta-diorite and metaultramafic rocks. Radiometric age determinations of four gneiss samples (K/Ar dating on either biotite or hornblende) yielded cooling ages of 2688-2335 Ma (Bridgwater 1971). A granulite facies migmatitic gneiss gave a protolith age of 2781 $\pm 6 \mathrm{Ma}$ (zircon U/Pb SHRIMP dating; Friend et al. 1996).

The supracrustal units comprise amphibolite, metapelite (biotite schist, garnet-quartz gneiss and biotite-garnet-sillimanite-corderite schist), calc-silicate rock and meta-ultramafic rocks including meta-dunite. A $2.8 \mathrm{Ga}$ zircon diffusion age is believed to represent the age of metamorphism and hence a minimum age for the formation of the supracrustal rocks (Andrews et al. 1973). A sample of an ordinary amphibolite unit yielded a cooling age of $2445 \pm 45 \mathrm{Ma}$ (biotite K-Ar dating, Bridgwater 1971).

\section{Preparation for field work}

Prior to the field work, in 2008 and the first half of 2009 , existing data and literature from the region were compiled in digital format and the existing 1:500 000 scale geological map of the region (Escher 1990) was modified, updated, and digitised (Fig. 1). Evenly distributed sampling stations were selected from (1) processed remote sensing data from which drainage systems and catchment basins were defined, (2) satellite images, (3) aerial photographs and (4) topographical data. All information and data are stored in a GIS database that will evolve in the coming years and finally comprise all data and observations from the region.

\section{Regional sampling procedure}

The regional sampling was carried out by two or three man teams using a helicopter or zodiacs. The chartered vessel M/V Fox served as a base. The preferred material for sediment sampling was fine-grained stream sediment from firstor second-order streams. In areas without drainage systems, sediment was collected from drift or scree slopes. The rationale behind sampling sediments is that their composition reflects the bedrock as well as results of possible mineralisation processes in the catchment area. The sediment samples were sieved and split in GEUS laboratories and the fine fraction $(<0.1 \mathrm{~mm})$ was analysed for 62 different elements at Activation Laboratories Ltd., Canada. Sediment samples were collected at 506 locations (Fig. 1).

In places with suitable drainage systems, the sediment samples were supplemented by surface water samples, with two samples collected at each locality. Measurements of $\mathrm{pH}$ 
and conductivity were carried out on one of the samples in the base camp. The other sample, which is used for geochemical analysis of 64 elements at the Activation Laboratories Ltd. in Canada, was acidified before storage. Water samples were collected at 379 localities.

A total of 138 coarse-grained sediment samples was collected for indicator mineral analysis from local drift. The rationale behind this type of sampling is that erosion products of a distinct or mineralised rock type can be traced in the drift, and that specific indicator minerals are diagnostic for the specific rock or process. For example, some minerals can be specific for kimberlite that may carry diamonds. Material was collected with a spade from below the vegetation, if present. Most commonly the drift was till, but locally glaciofluvial sediment was sampled. The material was sieved on a $6.35 \mathrm{~mm}$ screen fitted on top of a 20 litres bucket until a sample of $c .51$ was reached. The sieved material was then mixed and transferred to a 51 container for storage and shipment to the laboratory. The mineral grains will be evaluated by Overburden Drilling Management Ltd., Canada, for occurrence of kimberlite, $\mathrm{Au}-\mathrm{Ni}-\mathrm{Cu}$ and platinum-group element (PGE) indicator minerals.

Gamma-ray measurements were undertaken at the sample sites, using a portable multichannel gamma-ray spectrometer in order to determine total gamma radiation and concentration variations of $\mathrm{K}, \mathrm{U}$ and Th. Finally, representative rock types for geochemistry, petrological investigations and age determinations were collected.

\section{Preliminary results}

Based on the reconnaissance work, several types of mineralised rock were identified. All encountered mineral occurrences need more work to establish their settings and to assess their potential.

Small, metre-scale lenses of sulphide-bearing, metamorphosed ultramafic rocks, often hosted within mafic rock sequences ('supracrustal units') were found in the northern zone (Fig. 1; NZ). Several rusty horizons, up to tens of metres wide and continuous along strike for tens of kilometres, were seen within mafic to ultramafic rock sequences in both the northern zone and the central Skjoldungen alkaline province (Fig. 1; NZ and SAP). The horizons were found to contain disseminated or semi-massive to massive sulphide mineralisation with pyrrhotite, chalcopyrite and pentlandite and were encountered at several places along strike. Rock samples from this mineralisation show elevated concentrations of $\mathrm{Ni}, \mathrm{Cu}$ and $\mathrm{Cr}$ (grab samples have yielded up to $0.3 \% \mathrm{Ni}, 0.2 \% \mathrm{Cu}$, $0.5 \% \mathrm{Cr}, 24 \mathrm{ppb} \mathrm{Pt}$ and $162 \mathrm{ppb} \mathrm{Pd})$. These rock types may contain occurrences of orthomagmatic $\mathrm{Ni}, \mathrm{Cu}$ and PGE.

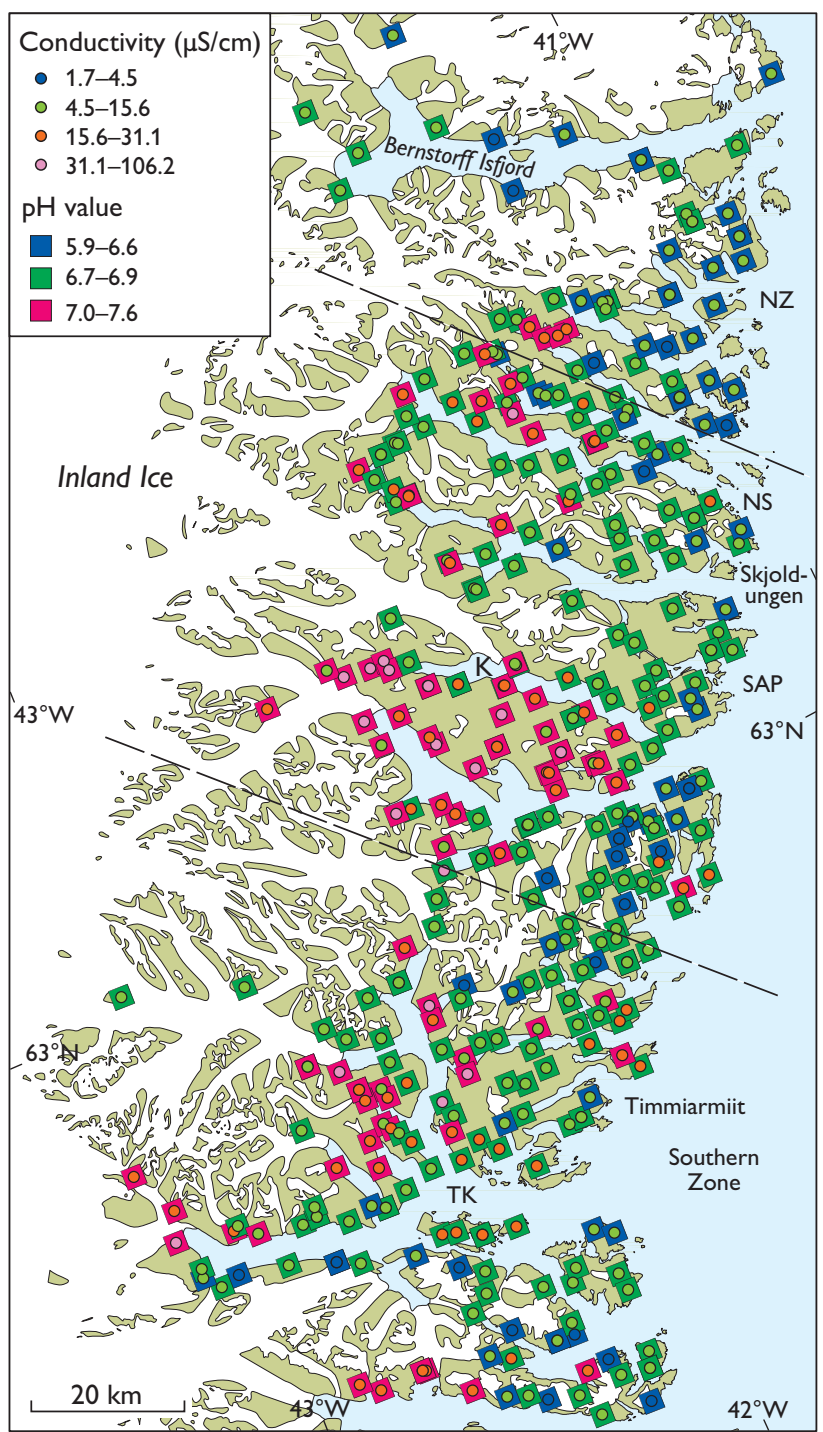

Fig. 2. Conductivity and $\mathrm{pH}$ from surface-water samples. The Skjoldungen alkaline province in the central part of the region shows high values of both conductivity and $\mathrm{pH}$. For abbreviations see text to Fig. 1.

Quartz veins within hydrothermal alteration zones (pyrrhotite-chalcopyrite-quartz-biotite-garnet) that are 10-20 m wide and traceable for $100 \mathrm{~m}$ to several kilometres along strike were found in the Skjoldungen alkaline province and in the southern zone. Even though samples have only yielded small gold concentrations (maximum $117 \mathrm{ppb} \mathrm{Au}$ ) it is notable that As, a pathfinder element for gold, shows elevated values (up to $1640 \mathrm{ppm} \mathrm{As}$ ). The alteration zones and the hydrothermal vein systems are potential gold targets.

The Skjoldungen alkaline province comprises the Singertât carbonatite complex (Nielsen \& Rosing 1990; Blichert-Toft $e t$ al. 1995). Rock samples from the carbonatite yielded a total rare-earth element (REE) concentration of c. $2500 \mathrm{ppm}$ to- 
gether with elevated values of Sr, Y and Ce (up to $2000 \mathrm{ppm}$ Sr, 120 ppm Y and 1100 ppm Ce). The surrounding orthogneisses also show elevated REE concentrations, which may be a result of a hydrothermal halo related to the complex.

The syntectonic gabbros, granites and syenites in the Skjoldungen alkaline province are rich in magnetite, and the general geological setting may indicate a potential for porphyry copper, tin or molybdenum deposits and iron-oxidecopper-gold deposits.

\section{Results from regional sampling}

The field-based gamma-ray measurements of the dominant rock types and the $\mathrm{pH}$ and conductivity measurements of surface water provide evidence for significant regional variations. Even though the range of both $\mathrm{pH}$ and conductivity values is limited, the measurements clearly reflect the intrusive suites of the Skjoldungen alkaline province, especially the syenites at Kattertooq and western Skjoldungen (Fig. 2), probably due to outwash of alkaline elements into surface waters from the syenites. This is supported by the gamma-ray measured $\mathrm{K}$ content, which is elevated within the Skjoldungen alkaline province. Elevated $\mathrm{pH}$, conductivity and $\mathrm{K}$ content are also seen in the eastern parts of the Kattertooq and Skjoldungen area, at Nordre Skjoldungesund and at Timmiarmiit in the south. From these data we suggest that alkaline magmatic rocks in the Archaean of South-East Greenland could be much more widespread than previously recognised.

\section{Further work}

The results of the analyses of sediment and surface-water samples and the results from the regional indicator-mineral analysis of material collected in 2009 were released in the spring 2010 (Minex 2010). Based on these results, the mining industry can evaluate the mineral potential of one of the least explored regions in Greenland. The data will also be used by GEUS and international research partners to improve our understanding of the geology of the region. The programme will continue in 2010 with similar work in the Tasiilaq region farther north. Many parts of this region are also poorly known and without basal regional data. In addi- tion, aeromagnetic surveys are being considered. The work in 2009 and 2010 provides a basis for more detailed geological work in 2011-2014. The aim of this work is to develop a wellconstrained geological model for the entire region which can justify exploration for ore deposits.

\section{Acknowledgements}

We gratefully acknowledge help and support from the skipper Niels Peter Trolle and his excellent crew on M/V Fox, from Air Greenland pilot Bertil Björk and mechanic Benny M. Sørensen, and friends in Tasiilaq and Kulusuk. The Greenland Bureau of Minerals and Petroleum supported the project financially.

\section{References}

Andrews, J.R., Bridgwater, D., Gormsen, K., Gulson, K., Keto, L. \& Watterson, J. 1973: The Precambrian of South-East Greenland. In: Park, R.G. \& Tarney, J. (eds): The early Precambrian of Scotland and related rocks of Greenland, 143-156. Birmingham University Press.

Blichert-Toft, J., Rosing, M.T., Lesher, C.E. \& Chauvel, C. 1995: Geochemical constraints on the origin of the Late Archean Skjoldungen alkaline igneous province, SE Greenland. Journal of Petrology 36, 515-561.

Bridgwater, D. 1971: Routine K/Ar age determinations on rocks from Greenland carried out for GGU in 1970. Rapport Grønlands Geologiske Undersøgelse 35, 52-60.

Chadwick, B., Dawes, P.R., Escher, J.C., Friend, C.R.L., Hall, R.P., Kalsbeek, F., Neilsen, T.F.D., Nutman, A.P., Soper, N.J. \& Vasudev, V.N. 1989: The Proterozoic mobile belt in the Ammassalik region, South-East Greenland, (Ammassalik mobile belt): an introduction and re-appraisal. Rapport Grønlands Geologiske Undersøgelse 146, 5-12.

Escher, J.C. 1990: Geological map of Greenland, 1:500 000, Sheet 14, Skjoldungen. Copenhagen: Geological Survey of Greenland.

Escher, J.C. \& Nielsen T.F.D. 1983: Archaean gneisses and supracrustal rocks of the Tingmiarmiut region, South-East Greenland. Rapport Grønlands Geologiske Undersøgelse 115, 79-82.

Friend, C.R.L., Nutman, A.P., Baadsgaard, H., Kinny, P.D. \& McGregor, V.R. 1996: Timing of late Archaean terrane assembly, crustal thickening and granite emplacement in the Nuuk region, southern West Greenland. Earth and Planetary Science Letters 142, 353-365.

Minex 2010: New data from South-East Greenland. Greenland Mineral Exploration newsletter 36, 2-3. Copenhagen: Geological Survey of Denmark and Greenland and Nuuk: Bureau of Minerals and Petroleum (available at www.geus.dk/minex).

Nielsen, T.F.D. \& Rosing, M.T. 1990: The Archaean Skjoldungen alkaline province, South-East Greenland. Rapport Grønlands Geologiske Undersøgelse 148, 93-100.

\footnotetext{
Authors' addresses

B.M.S., J.K., T.F.D.N., S.O.L. \& L.P., Geological Survey of Denmark and Greenland, Øster Voldgade 10, DK-1350 Copenhagen K, Denmark. E-mail:

bmst@geus.dk

D.L., Weidekampsgade 27, 2. t.v., DK-2300 Copenhagen S, Denmark.

A.C., Bureau of Minerals and Petroleum, P.O. Box 930, DK-3900 Nuuk, Greenland.
} 